\title{
Firms' Price-Markup Dynamics During the Great Recession
}

\author{
Sungki Hong, Economist
}

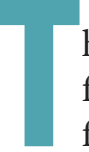
he 2007-09 Great Recession was a turbulent period for the U.S. economy: The growth rate of real GDP fell from 2.7 percent in 2007:Q3 to -8.2 percent in 2008:Q4; the unemployment rate sharply increased from a pre-recession average of 4.5 percent to an average of above 9 percent; and gross domestic private investment dropped by more than 20 percent. In spite of the severe economic slack, the inflation rate did not fall as much as suggested by the Phillips curve, which governs the empirical relation between the inflation rate and unemployment rate. John C. Williams, the president of the Federal Reserve Bank of San Francisco, said that “[a]ctually, the surprise isn't that inflation has fallen. The surprise is that it's fallen so little, given the depth and duration of the recent downturn. Based on the experience of past severe recessions, I would have expected inflation to fall by twice as much as it has."

\section{The customer capital model is consistent with Great Recession markup dynamics.}

One potential explanation for the missing disinflation is the upward pressure in pricing through an increase in the desired markup. A markup is the margin of price over the marginal cost of production set by firms. In a previous article, "Price Markups for Small and Large Firms Over the Business Cycle," I document that markups tend to rise during economic busts. Moreover, with micro-level data, I find that the markups of small firms rise relatively more than those of large firms.

There is a long line of empirical studies regarding pricemarkup fluctuations over business cycles. However, economists have not reached a consensus on the determinants of markup movements. Many economic models in the literature generate variable price markups. One approach is to assume that firms' markups follow an exogenous process and vary over time. In contrast, other approaches rely on models that rationalize the variable markups with micro foundations.
However, which model is consistent with the empirical observation? The aim of this essay is to examine two main models widely used in the literature and to see how each aligns with the empirical findings of the Great Recession. In particular, I study the following two models: (i) an oligopolistic competition model and (ii) a customer capital model.

First I consider the oligopolistic competition model as in Atkeson and Burstein (2008). In the model, firms with different productivity levels (or firm-product appeal) compete to gain market share. In equilibrium, the firm with the highest productivity gets the largest market share and charges the highest markup, while the firm with the lowest productivity gets the smallest market share and charges the lowest markup. Also, internalizing its impact on the market, a large firm would be more sluggish in changing its price after a shock to its marginal cost. This translates into more volatile markup movements for large firms.

The model-implied markups can be calculated based on the theoretical mapping between the markup and the market share in revenues. To test the performance of the oligopolistic competition model, I run the following fixedeffect regression:

$$
\log \mu_{i t}^{O C}=\alpha_{i}+\beta_{2007-2009}+\varepsilon_{i t},
$$

where $\mu_{i t}^{O C}$ is the firm-level markup calculated from the Atkeson-Burstein specification, $\alpha_{i}$ is the firm fixed effect, and $\beta_{2007-2009}$ measures the average increase in the markup of all firms during 2007-09.

We see in Table 1 that the oligopolistic competition model predicts that average markups increased by 29 percent during the 2007-09 recession. This is because, as many firms exited during the recession, the remaining firms gained more market share, hence raising markups. Furthermore, I group firms by size-small and large-where small firms have less than 1 percent market share within their four-digit industry and where large firms have more than 1 percent market share. By comparing the results in columns (2) and (3), we see that the movements of both small 
Table 1

Oligopolistic Competition Model

\begin{tabular}{lccc}
$\begin{array}{l}\text { Dependent variables } \\
\log \mu_{i t}^{O C}\end{array}$ & $\begin{array}{l}(\mathbf{1}) \\
\text { All }\end{array}$ & $\begin{array}{c}(\mathbf{2}) \\
\text { Small }\end{array}$ & $\begin{array}{c}\text { (3) } \\
\text { Large }\end{array}$ \\
\hline$\beta_{2007-2009}$ & $0.29^{* * *}$ & $0.28^{* * *}$ & $0.35^{* * *}$ \\
\hline Firm fixed effect & $(0.00)$ & $(0.00)$ & $(0.01)$ \\
\hline Number of observations & Yes & Yes & Yes \\
\hline Adjusted $R^{2}$ & 21,295 & 16,276 & 5,019 \\
\hline
\end{tabular}

NOTE: Standard errors are in parentheses. ${ }^{*} p<0.10,{ }^{* *} p<0.05,{ }^{* *} p<0.01$. SOURCE: Bureau van Dijk (BvD) Amadeus, FRED ${ }^{\oplus}$, and author's calculations.

and large firms' markups are inconsistent with the empirical evidence. Small firms' markups have increased by only 28 percent, while large firms' markups have increased by 35 percent. This result is not surprising, since the oligopolistic competition model results in more-variable markups for large firms.

Next I consider the customer capital model. Customer capital is endogenously accumulated and determines the level of demand of firms' outputs. To enlarge its customer capital, a firm can sell more of its products today to gain more market share in the future. In other words, a firm sees product sales as a form of investment in customer capital. The firm wants to lower its price to attract customers to invest in its own customer capital, and it has an incentive to lock in customers by lowering its price. However, the firm faces a trade-off with the harvest motive. Because a firm has a certain degree of market power over the locked-in customers, it wants to raise its price to harvest the profit. In a recession, because a small firm is more likely to exit the market, it puts less weight on the future benefit of customer capital and raises its price to harvest from customers as much as possible before exiting the market.

To test the customer invest-harvest channel, I run the following regression:

$$
\log \hat{\mu}_{i t}=\alpha_{i}+\beta_{2007-2009} E X I T_{i t}+\varepsilon_{i t},
$$

where $\hat{\mu}_{i t}$ is the firm-level markup estimated in the data, $\alpha_{i}$ is the firm fixed effect, and EXIT $T_{i t}$ is a dummy variable that indicates the firm's exit decision. If the firm exits the
Table 2

\section{Customer Capital Model}

\begin{tabular}{|c|c|c|c|}
\hline $\begin{array}{l}\text { Dependent variables } \\
\log \hat{\mu}_{i t}\end{array}$ & $\begin{array}{l}\text { (1) } \\
\text { All }\end{array}$ & $\begin{array}{c}(2) \\
\text { Small }\end{array}$ & $\begin{array}{c}(3) \\
\text { Large }\end{array}$ \\
\hline$\beta_{2007-2009}$ & $\begin{array}{l}0.051^{* * *} \\
(0.012)\end{array}$ & $\begin{array}{l}0.056^{* * *} \\
(0.013)\end{array}$ & $\begin{array}{l}0.034^{* * *} \\
(0.007)\end{array}$ \\
\hline Firm fixed effect & Yes & Yes & Yes \\
\hline Number of observations & 21,295 & 16,276 & 5,019 \\
\hline Adjusted $R^{2}$ & 0.93 & 0.93 & 0.92 \\
\hline
\end{tabular}

NOTE: Standard errors are in parentheses. ${ }^{*} p<0.10,{ }^{* *} p<0.05,{ }^{* * *} p<0.01$. SOURCE: BvD Amadeus, FRED ${ }^{\circledR}$, and author's calculations.

economy in the next period, the dummy variable equals 1; and if the firm does not exit in the next period, the dummy variable equals zero.

The results from column (1) in Table 2 suggest that, on average, exiting firms raise markups by 5.1 percent more than firms that continue to operate in the economy. Moreover, the effect of the exit decision is stronger for small firms than for large firms. By comparing columns (2) and (3), we see that the EXIT it raises small firms' markups by 2.2 percent more than large firms.

Overall, although both models suggest that overall markups increased in the 2007-09 recession, the customer capital model does a better job at explaining the micro-level evidence in the data. In fact, I think the customer capital model deserves increased attention from researchers, at least as much as if not more than the competition model and the sticky price model. However, more theoretical work regarding customer markets or marketing is needed.

\section{References}

\begin{abstract}
Atkeson, Andrew and Ariel Burstein. "Pricing-to-Market, Trade Costs, and International Relative Prices." American Economic Review, 2008, 98(5), pp. 1998-2031; https://doi.org/10.1257/aer.98.5.1998.

Hong, Sungki. "Price Markups for Small and Large Firms Over the Business Cycle." Federal Reserve Bank of St. Louis Economic Synopses, 2018, No. 17; https://doi.org/10.20955/es.2018.17.
\end{abstract}

Williams, John. "Sailing Into Headwinds: The Uncertain Outlook for the U.S. Economy," in Presentation to Joint Meeting of the San Francisco and Salt Lake City Branch Boards of Directors, Salt Lake City, UT, 2010. 